\title{
Pollination and quality of seeds and plantlets of Eugenia uniflora L.
}

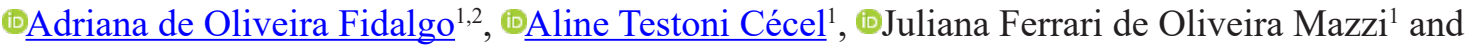

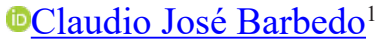

Received: 29 January 2018; accepted: 12 November 2018

How to cite: Fidalgo, A.O., Cécel, A.T., Mazzi, J.F.O. \& Barbedo, C.J. 2019. Pollination and quality of seeds and plantlets of Eugenia uniflora L. Hoehnea 46: e052018. http://dx.doi.org/10.1590/2236-8906-05/2018.

\begin{abstract}
Pollination and quality of seeds and plantlets of Eugenia uniflora L.). This work evaluated the effect of pollination on the quality of seeds and plantlets of Eugenia uniflora L., as well as on the regenerative capacity of the seeds. Twelve individuals were monitored for their phenology and their floral visitors. Recently-opened flowers were subjected to self-pollination (SP), cross-pollination (CP) and natural pollination/control (C) treatments. The seeds obtained were evaluated for their germination and the resulting seedlings were transferred to a greenhouse and evaluated for their height, stem diameter, number of leaves, leaf area and fresh and dry mass of root, stem, and leaves. SP, CP and C seeds were fractionated into two and four parts and evaluated for their ability to germinate and produce normal seedlings. Seeds and seedlings from manual cross-pollination were the most vigorous. The worst performance of the natural pollination $(\mathrm{C})$ evidenced the pollen limitation caused by the scarcity of efficient pollinators in the study area.
\end{abstract}

Keywords: effective pollinators, Myrtaceae, reproductive biology, seedlings.

RESUMO - (Polinização e qualidade de sementes e mudas de Eugenia uniflora L.). Este trabalho avaliou o efeito da polinização na qualidade de sementes e mudas de Eugenia uniflora L., assim como na capacidade de regeneração das sementes. Doze indivíduos tiveram sua fenologia e seus visitantes florais acompanhados. Flores recém-abertas foram submetidas aos tratamentos de autopolinização (AP), polinização cruzada (PC) e controle (polinização natural, C). As sementes obtidas foram avaliadas quanto à germinação e as suas plântulas foram transferidas para estufa e avaliadas quanto à altura, diâmetro do colo, número de folhas, área foliar e massa fresca e seca de raiz, caule e folhas. Sementes de AP, PC e C foram fracionadas em duas e quatro partes e avaliadas quanto à manutenção da capacidade em germinar e produzir plântulas normais. Sementes e mudas oriundas da polinização cruzada manual foram as mais vigorosas. O pior desempenho da polinização natural (C) evidenciou a limitação polínica gerada pela escassez de polinizadores eficientes na área de estudo.

Palavras-chave: biologia reprodutiva, Myrtaceae, plântulas, polinizadores efetivos.

\section{Introduction}

Eugenia uniflora L. (pitangueira), a fruiting species of the Myrtaceae family, has hermaphrodite flowers with a high number of stamens. They produce large quantities of pollen grains, the main floral resource offered to visitors including wasps, flies, birds, and mainly bees (Proença \& Gibbs 1994, Nic Lughadha \& Proença 1996, Fidalgo \& Kleinert 2009, Diniz \& Buschini 2016). Its mass flowering pattern is a strategy to attract pollinators, a feature of self-compatible plants that benefit from the presence of these to increase their fruit set (Beardsell et al. 1993, Franzon et al. 2010). E. uniflora presents a mixed reproductive system, high levels of alogamy and autogamy, facing the advantages and costs of both systems, such as the possibility of adjusting the reproductive strategy to the availability of pollinators, the risks of depression due to inbreeding and the loss of well-adapted genotypes in cross-pollination (Lloyd 1992, Barringer 2007, Santos et al. 2010, Franzon et al. 2010).

The main method of propagation for the species is through seeds (Bezerra et al. 2000). Although the ovary presents about twenty ovules per locule, the fruits produce, in general, a single seed leading to the supposition of seed abortion or a restriction on fertilization caused by genetic factors (Silva \& Pinheiro 2007, 2009).

Seeds of some species of Eugenia can germinate even after being cut, increasing the number of

1. Instituto de Botânica, Núcleo de Pesquisa em Sementes, Av. Miguel Stefno 3.687, CEP 04301-902 São Paulo, SP, Brasil

2. Corresponding author: aofidalgo@hotmail.com 
seedlings formed from the same batch (Silva et al. 2005, Delgado et al. 2010). This suggests the presence of meristematic tissues capable of differentiating, forming new embryos, from the tissues of the cotyledonary vascular region (Delgado 2010). This unusual ability to develop seedlings even after removal of half (or more than half) of their storage tissue may be related to the species survival strategies (Teixeira \& Barbedo 2012). On the other hand, the development of only one new seedling in each seed fragment suggests the presence of a control system, with a balance between the stimulus to form a new seedling from the cut and the inhibition of the development of a second one (Amador \& Barbedo 2011). One of the factors that can influence this process is the genetic control, as verified in Campomanesia pubescens, another species of the family (Rodrigues et al. 2017).

The knowledge about pollination, reproduction and variability among populations is very important for management, breeding and preservation of species (Franzon et al. 2010), both from the point of view of conservation and commercial production (Silva $\&$ Pinheiro 2007). Therefore, detailed studies on the species reproductive biology need to be conducted to determine the influence of their reproductive systems on the quality of the seeds and seedlings obtained, and on regeneration processes, as described for them. The objective of the present study was to evaluate the influence of pollination and reproduction system on the quality of seeds and seedlings from Eugenia uniflora. Furthermore, we evaluated the interference of reproductive processes on the regeneration potential of seeds.

\section{Material and methods}

This work was carried out in the Parque Estadual das Fontes do Ipiranga, São Paulo, SP (23 $38^{\circ}$ '08"S and $23^{\circ} 40^{\prime} 18^{\prime \prime} \mathrm{S}-46^{\circ} 36^{\prime} 48^{\prime \prime} \mathrm{W}$ and $46^{\circ} 38^{\prime} 00^{\prime \prime} \mathrm{W}$ ) between the years 2014 and 2016. The climate in the region is subtropical, type Cwa, characterized by a notably dry winter and a very rainy summer (Köppen 1948), with an annual average temperature of $20.7^{\circ} \mathrm{C}$ (CEPAGRI 2012).

Phenology was monitored to determine the relation of the reproductive events with abiotic factors and to describe variations in the flowering and fruiting moments. Monthly observations were made from January 2014 to December 2016. The numbers of flower buds, open flowers, and mature fruits were counted (Fidalgo \& Kleinert 2009). Data were sorted by period, transformed into proportions, and plotted in phenograms. Then, data were analyzed by means of circular statistics (Batshelet 1981) in order to determine the period of the greatest flowering intensity of the species. The mean length of the " $r$ " vector is the concentration measure (minimum: 0, maximum: 1) (Batschelet 1981, Zar 1999). The Rayleigh test was used to obtain the significance of the acrophases and the Watson-Williams test was performed to compare the periods of greater intensity of the phenophases between the years of study (Zar 1999).

The set of floral visitors was determined by the observation and collection of the animals, with the aid of an entomological net, during the morning period, throughout the flowering of the individual plants in the study period. The insects collected were identified in the Museum of Zoology of the University of São Paulo, where they are deposited.

In 2014, controlled pollination experiments were carried out to describe the species reproductive system and its effect on the quality of its seeds and seedlings. Pre-flowering buds of 8 individuals were bagged to evaluate the occurrence of spontaneous self-pollination and the consequences of pollinator exclusion. Apomixis tests were not performed considering that styleless buds of E. uniflora do not develop into fruit (Silva \& Pinheiro 2009). Recently opened flowers were submitted to manual self- and cross-pollination treatments (Dafni et al. 2005). The control group consisted of non-bagged flowers exposed to natural pollination. The fruits were collected separately at the end of maturation, manually macerated and washed in running water, on sieves, to separate the seeds (Delgado \& Barbedo 2007).

The occurrence of pollen limitation was evaluated using the pollen limitation index [IPL = 1 - $(\mathrm{Fn} / \mathrm{Fcp})]$; where $\mathrm{Fn}$ is the percentage of fruiting under natural conditions and Fcp is the percentage of fruiting under manual cross-pollination. Negative values or close to zero (0.2) indicate the absence of pollen limitation (PL) (Larson \& Barret 2000, Freitas et al. 2010).

To evaluate germinability, seeds from each pollination treatment were stored in a gerbox containing approximately $200 \mathrm{ml}$ of sand and vermiculite $(1: 1)$ as a substrate, and incubated in a germination room at $25^{\circ} \mathrm{C}$ and continuous light. In the laboratory, the seeds were monitored daily, with the germinated seeds (seeds with $5 \mathrm{~mm}$ root protrusion) and the formation of normal seedlings (emission of the first two leaflets without deformed or damaged parts) up to 120 days. 
After the development in the laboratory, the seedlings with about $5 \mathrm{~cm}$ in height and a pair of leaflets developed in the dark green color were transferred to the greenhouse. To accommodate them, 5-liter polypropylene pots filled with 3 liters of the substrate were used. At the bottom of the containers, a layer of drainage stones was deposited and, on top of this, there was a substrate prepared with $50 \%$ of Red-Yellow Latosol with clayey texture and $50 \%$ of Forth ${ }^{\circledR}$ organic compound.

Plantlets were kept in the greenhouse (531.46 $\mu \mathrm{mol}$ photons $\left.\mathrm{m}^{-2} \mathrm{~s}^{-1}\right)$ under controlled irrigation conditions ( 3 times a week). The parameters analyzed were: shoot height (h), stem diameter (SD) and the number of leaves (NL). These variables were evaluated every two weeks up to 180 days after the start of the experiment.

On day 90 and 180, 15 plantlets per treatment were removed from the pots, washed, to separate the residues from the substrate and evaluated for the following parameters: leaf area (LA, estimated with the aid of LICOR ${ }^{\circledR}$ leaf area integrator model LI-3100) and root, stem and leaf fresh matter. After drying in a stove at $65^{\circ} \mathrm{C}$ for 24 hours, leaf dry matter (LDM), stem dry matter (SDM) and root dry matter (RDM) were evaluated. In addition, the shoot dry matter $(\mathrm{SDM}=\mathrm{LDM}+\mathrm{SDM})$, the total dry matter $(\mathrm{TDM}=\mathrm{SDM}+\mathrm{RDM})$, the shoot/root system ratio $(\mathrm{SRR}=\mathrm{SDM} / \mathrm{RDM})$, the relation between shoot height/stem diameter (hSDR) and the Dickson quality index (DQI) were calculated, using the formula $\mathrm{DQI}=[\mathrm{TDM} /(\mathrm{hSDR}+\mathrm{SRR})]($ Dickson et al. 1960, Carneiro 1995, Fonseca et al. 2002).

The mean values of the development parameters were, after data normality analysis (Zar 1999), compared per treatment through mean comparison tests using the SISVAR statistical package (Ferreira 1999).

In the years of 2015 and 2016, controlled pollination experiments were carried out again to evaluate the regeneration potential of the seeds produced in manual self- and cross-pollinations and in the control group. The fruits formed were collected separately at the end of maturation and macerated to separate the seeds as described above.

These seeds were fractionated with the aid of a scalpel and all the fractions of each pollination treatment were placed to germinate. The following treatments were performed: 1 . intact seeds (control group); 2 . seeds sectioned in the middle, transversely to their longer length, trying to pass the cut through the hilum (cut 2); 3. Seed sectioned radially in four parts (cut 4), the first cross-section was transverse to the length, the second one was orthogonal to the first (Silva et al. 2003). In this way, nine treatments were obtained, in a $3 \times 3$ factorial scheme (pollination $\times$ fractions).

In order to evaluate germination, the seeds (or fractions of seeds) were placed in a gerbox containing $2 \mathrm{~cm}$ of vermiculite saturated with water as a substrate and incubated in a germination room at $25{ }^{\circ} \mathrm{C}$ and continuous light. We recorded seeds (or fractions of seeds) with primary root protrusion of at least $5 \mathrm{~mm}$ in length, to obtain the germination rate, and seeds (or fractions of seeds) with present root system and epicotyl with visible leaves (Delgado \& Barbedo 2007), for the calculation of the rate of seeds capable of producing normal seedlings (Normal Seedling Development - NSD). The germination test was ended on day 120 .

\section{Results}

Eugenia uniflora L. has racemic inflorescences, with white flowers that offer only pollen as a resource and have many stamens organized in a shaving brush shape. Anthesis occurred around 6:00 a.m. and the flowers lasted for only a day.

The flowering pattern presented in the species was annual and in mass, and reproduction occurred between July and December when the rainfall tends to increase in the region (figure 1). Reproductive events were generally concentrated between the months of August and September $(r=0.757 ; p<0.05)$ (figure 1b).

The peak bud formation occurred at the beginning of July in $2014(\mathrm{r}=0.934, \mathrm{p}<0.05)$ and was delayed for the first and second fortnights of August in the following two years $(r=0.948$ and $r=0.983, p<0.05$, respectively). Flowering showed peaks of intensity in the last two weeks of July $2014(\mathrm{r}=0.918, \mathrm{p}<0.05)$, in the first half of August $2015(\mathrm{r}=0.968, \mathrm{p}<0.05)$, and in the first two weeks of September $2016(\mathrm{r}=0.952$, $\mathrm{p}<0.05$ ). Consequently, fruiting occurred with greater intensity between the first half of October $(\mathrm{r}=0.966$ and $0.962, p<0.05$, in 2014 and 2015, respectively) and the first half of November $(r=0.956, p<0.05)$.

According to the Watson-Williams test, the peak intensity of the reproductive events of E. uniflora was significantly different between the years 2014, 2015 and $2016\left(\mathrm{~F}_{\text {critical }} 0.05(1) .1 .198=3.89\right)$. These variations may be related to changes in precipitation 

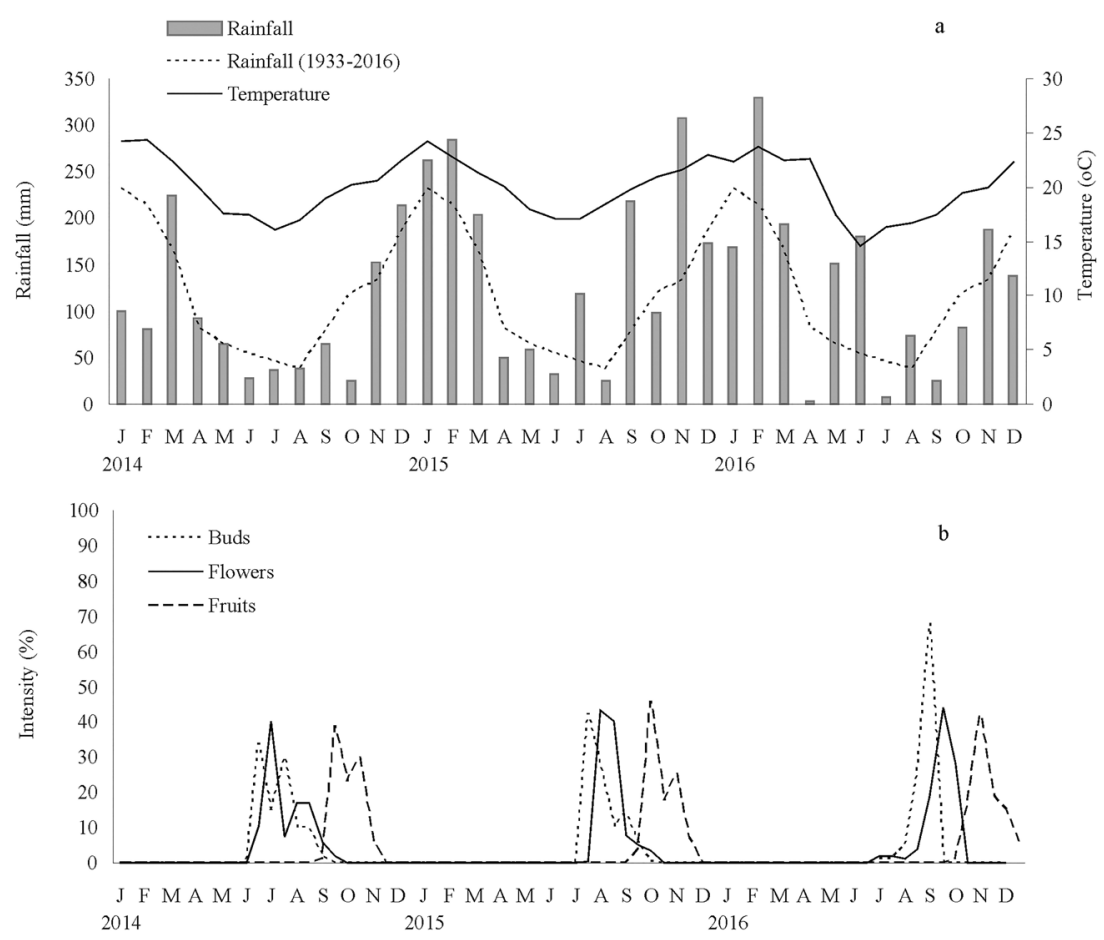

Figure 1. A. Average monthly rainfall $(\mathrm{mm})$ and temperature $\left({ }^{\circ} \mathrm{C}\right)$ for the municipality of São Paulo between 2014 and 2016. The dashed line indicates the average monthly rainfall ( $\mathrm{mm}$ ) for the historical series between 1933 and 2016 (source: IAG/USP weather station, http:// www.estacao.iag.usp.br/boletim.php). B. Intensity (\%) of the reproductive phenophases of Eugenia uniflora L. at the Parque Estadual das Fontes do Ipiranga between 2014 and 2016.

patterns, relative to the climatological average, observed from August 2015 (figure 1a).

As for floral visitors, tagged individuals were visited by a small number of insects belonging to the family Apidae, more frequently between 7:00 and 9:00 a.m. The species or genera identified were Apis mellifera Linnaeus, 1758, Paratrigona subnuda Moure, 1947, Augochloropsis sp., Bombus sp., e Paroxystoglossa sp.

According to the data in table 1, the highest reproductive success in E. uniflora was observed in the treatment of cross-pollination in the three years of study, followed by manual self-pollination and the control group. The spontaneous self-pollination treatment was performed just in the first year of study and its success rate was only higher than that of the control group. The percentage of seed germination was similar among the treatments with little variation between the years. The number of seeds per fruit was 1.0 in all treatments with the exception of crosspollination with an average number of seeds per fruit equal to $1.36( \pm 0.77 ; n=282)$. The IPL was equal to 0.76 in 2014 and 0.90 in 2015 and 2016.

The germination of all treatments occurred between five and 25 days, with an evident peak at 15 days for the control and cross-pollination treatments, and with two peaks (at 5 and at 20-25 days) for the other treatments (figure 2a). Manual and spontaneous self-pollination and the control group formed normal seedlings between 15 and 50 days with peaks around 25 and 40 days (figure $2 \mathrm{~b}$ ). In cross-pollination, normal seedlings arose later and for a longer period between 25 and 90 days with some arising at 100/105 days after sowing.

According to the morphological parameters studied, the plantlets from the cross-pollination showed a better development at both 90 and 180 days after transplanting to the greenhouse, being clearly larger in relation to shooting height as well as stem diameter (table 2).

In addition, plantlets from cross-pollination presented mean values higher than the other treatments in the SDM and TDM at both 90 and 180 days (table 3 ). Regarding DQI, at 90 days, the highest values were those of the control and self-pollination treatments, respectively, and at 180 days, cross-pollination was superior to all other treatments (table 4).

Regarding the fractioning and regeneration experiments, in 2015 the germination peak occurred 
Table 1. Results of reproductive success (\%) and seed germination (\%) obtained through the pollination treatments in Eugenia uniflora L., between 2014 and 2016.

\begin{tabular}{lcccccc}
\hline Treatment & \multicolumn{3}{c}{ \% Success (flowers/fruits) } & \multicolumn{3}{c}{ \% Germination } \\
\cline { 2 - 6 } & 2014 & 2015 & 2016 & 2014 & 2015 & 2016 \\
\hline Spontaneous & 15.4 & -- & -- & 93.6 & -- & -- \\
self-pollination & $(422 / 65)$ & & & & & \\
Self-pollination & 23.5 & 6.6 & 3.1 & 95.5 & 100.0 & 100.0 \\
& $(302 / 71)$ & $(287 / 19)$ & $(1153 / 36)$ & & & 98.0 \\
Cross-pollination & 38.3 & 40.6 & 24.2 & 89.8 & 96.0 & \\
& $(222 / 85)$ & $(165 / 67)$ & $(537 / 130)$ & & & 88.3 \\
Control & 9.1 & 4.1 & 2.4 & 93.6 & 93.0 & \\
\hline
\end{tabular}
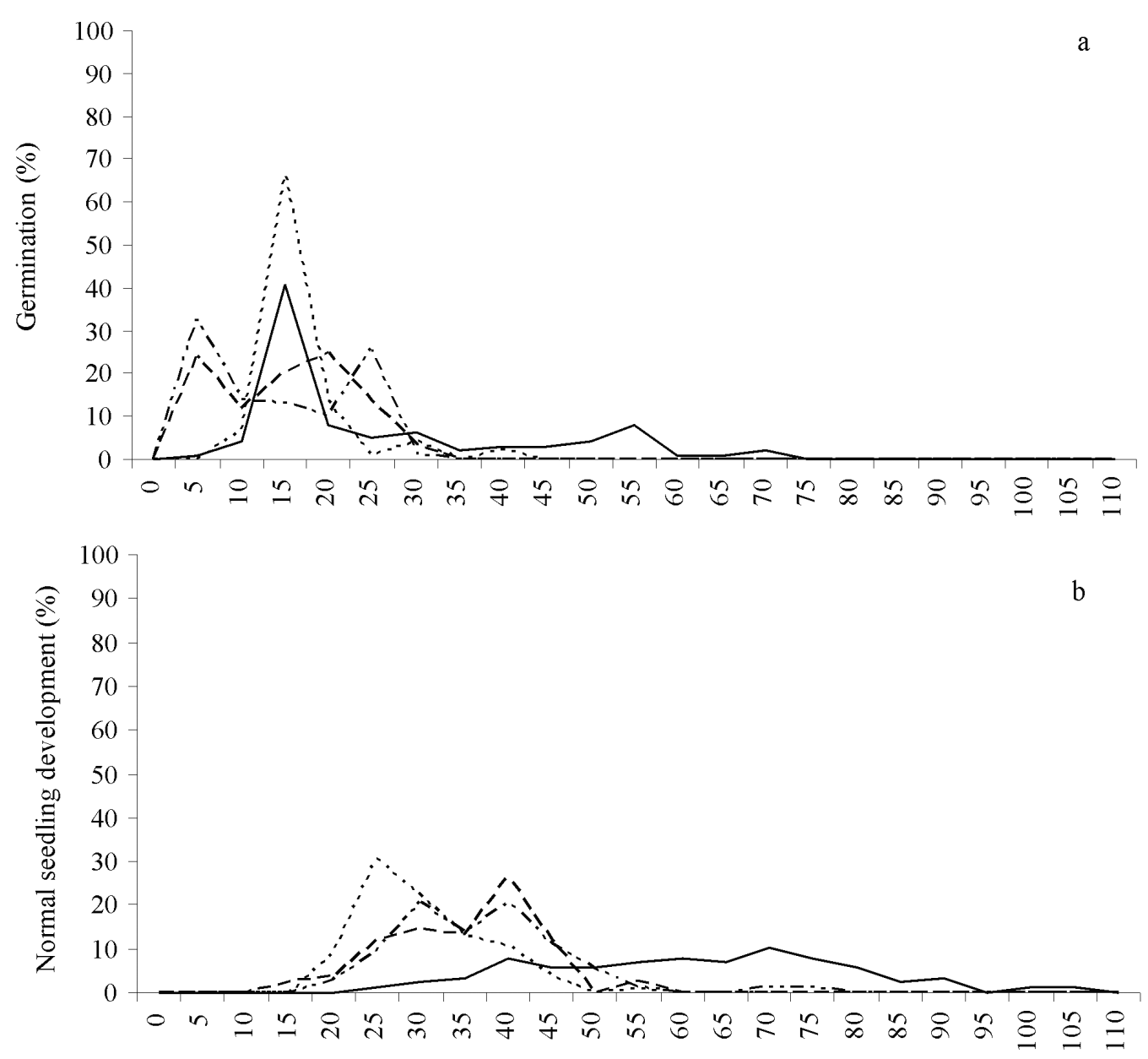

Days

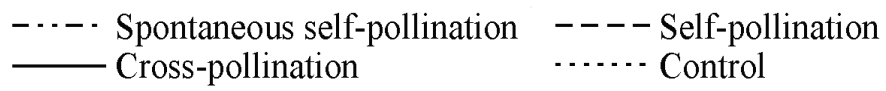

Figure 2. Temporal distribution of germination (\%) and normal seedling development (\%), A and B respectively, for seeds of Eugenia uniflora L., according to the pollination treatment. 
Table 2. Mean of the morphological parameters evaluated on day 90 and 180 after the beginning of greenhouse experiments, according to the pollination treatment. h: shoot height $(\mathrm{cm})$; SD: stem diameter $(\mathrm{mm})$; NL: number of leaves; $\mathrm{n}=30^{*}$.

\begin{tabular}{lccrrr}
\hline Days after transplanting & & $\begin{array}{c}\text { Spontaneous self- } \\
\text { pollination }\end{array}$ & Self-pollination & Cross-pollination & Control \\
\hline \multirow{4}{*}{90} & $\mathrm{~h}$ & $11.00( \pm 2.30) \mathrm{a}$ & $12.00( \pm 1.10) \mathrm{ab}$ & $17.10( \pm 2.10) \mathrm{c}$ & $12.40( \pm 0.80) \mathrm{b}$ \\
& $\mathrm{SD}$ & $1.72( \pm 0.24) \mathrm{a}$ & $1.72( \pm 0.25) \mathrm{a}$ & $2.19( \pm 0.27) \mathrm{b}$ & $1.72( \pm 0.19) \mathrm{a}$ \\
& $\mathrm{NL}$ & $11.00( \pm 2.00) \mathrm{a}$ & $10.00( \pm 2.00) \mathrm{a}$ & $13.00( \pm 2.00) \mathrm{b}$ & $11.00( \pm 3.00) \mathrm{a}$ \\
\hline \multirow{4}{*}{180} & $\mathrm{~h}$ & $11.80( \pm 3.20) \mathrm{a}$ & $12.90( \pm 4.10) \mathrm{a}$ & $18.00( \pm 5.40) \mathrm{b}$ & $13.20( \pm 1.30) \mathrm{a}$ \\
& $\mathrm{SD}$ & $2.37( \pm 0.38) \mathrm{a}$ & $2.34( \pm 0.41) \mathrm{a}$ & $3.43( \pm 0.94) \mathrm{b}$ & $2.34( \pm 0.29) \mathrm{a}$ \\
& $\mathrm{NL}$ & $14.00( \pm 5.00) \mathrm{a}$ & $13.00( \pm 5.00) \mathrm{a}$ & $18.00( \pm 8.00) \mathrm{b}$ & $13.00( \pm 2.00) \mathrm{a}$ \\
\hline
\end{tabular}

* Different letters indicate differences between treatments within each evaluation (90 and 180 days), compared by Tukey's test at $5 \%$.

between 5 and 20 days for intact seeds from manual pollinations, whereas for the seeds of the control group the peak was later, occurring between 15 and 25 days (figure 3a). Seeds sectioned in two parts presented late peak for self-pollination and control (figure 3c). When fractionated, seeds from cross-pollination had the germination extended, reaching 95 days for the seeds cut in four parts (figure 3e). In 2016, the germination peak occurred between 10 and 15 days for seeds intact and cut in two parts from the three pollination treatments (figure $3 b$ and $d$ ). Seeds sectioned in four parts showed germination peak between 10 and 20 in all pollination treatments, with two peaks occurring for cross-pollination during this period (figure $3 \mathrm{f}$ ). Again, the germination was extended in the fractionated seeds from cross-pollination, reaching 125 days for the sectioned in four parts (figure $3 \mathrm{f}$ ).

In the two-year study, intact seeds from manual pollination had higher germination rates compared to the ones from the control group (figure 4a and b). In 2015, when the seeds were split in two, the percentage of germination was around $150 \%$ in all pollination treatments. When sectioned in four parts, the seeds from the control group presented $170 \%$ of germination, decreasing to $143 \%$ for seeds from self-pollination and increasing to $200 \%$ from crosspollination. In 2016, it was possible to observe that the seeds from the control group obtained inferior results comparing to the previous year (figure $4 b$ ). When the seeds were sectioned in two parts the germination reached $103 \%$ in control, increasing to $131 \%$ in selfpollination and reaching $179 \%$ in cross-pollination. This was also observed when the seeds were sectioned in four parts, in which the germination reached 135\% in the control, increasing to $146 \%$ in self-pollination and reaching $269 \%$ in cross-pollination.
In the first year of study, when the seeds were sectioned, the percentage of normal seedlings formed increased in all treatments, except in self-pollination (figure 4c). Intact seeds from self-pollination reached $71 \%$ of normal seedlings followed by the control group (83\%) and by cross-pollination (96\%). When the seeds were sectioned the percentage of normal seedlings reached $108 \%$ in cross-pollination, but did not exceed $95 \%$ in control and $86 \%$ in self-pollination.

In 2016, fractioning the seeds led to a decreased amount of normal seedlings only in self-pollination (figure 4d). Intact seeds from the control group showed $55 \%$ of normal seedlings and $92 \%$ in cross-pollination treatments. When the seeds were sectioned, this percentage was reduced to $77 \%$ in self-pollination and increased to $70 \%$ in the control group. In crosspollination, sectioned seeds formed more than $100 \%$ of normal seedlings, reaching $183 \%$ for seeds cut in four parts.

Seeds non-germinated were discarded from the analysis presented on table 4. In the year 2015, significant differences are not observed between treatments in relation to seed germination and normal seedling development. However, in 2016, crosspollination treatment presented better performance in both parameters.

\section{Discussion}

Eugenia uniflora presents generalist flowers that offer pollen as the main attraction for pollinators. Its mass flowering pattern and the short duration of its flowers are common to other Myrtaceae species (Nic Lughadha \& Proença 1996, Silva \& Pinheiro 2007, Fidalgo \& Kleinert 2009, Diniz \& Buschini 2016, Rodrigues et al. 2017). 
Table 3. Mean and standard deviation of the parameters SDM(g), TDM(g), TDM (\%), SRR, hSDR and DQI of Eugenia uniflora L. plantlets on 90 and 180 days. SDM: shoot dry matter; TDM: total dry matter; SRR: shoot/root relation; hSDR: height/stem diameter relation; DQI: Dickinson quality index.*

\begin{tabular}{lcccrrr}
\hline \multirow{2}{*}{ Treatment } & \multicolumn{5}{c}{90 days } \\
\cline { 2 - 7 } & SDM $(\mathrm{g})$ & TDM $(\mathrm{g})$ & TDM $(\%)$ & SRR & hSDR & DQI \\
\hline Spontaneous self-pollination & $0.207 \mathrm{a}$ & $0.328 \mathrm{ab}$ & 36.0 & 2.55 & 7.63 & 2.60 \\
& \pm 0.088 & \pm 0.139 & \pm 4.5 & \pm 3.29 & \pm 1.97 & \\
Self-pollination & $0.186 \mathrm{a}$ & $0.272 \mathrm{a}$ & 32.6 & 3.65 & 7.52 & 3.69 \\
& \pm 0.088 & \pm 0.128 & \pm 4.5 & \pm 4.78 & \pm 1.03 & \\
Cross-pollination & $0.496 \mathrm{~b}$ & $0.709 \mathrm{c}$ & 35.8 & 2.83 & 7.99 & 2.91 \\
& \pm 0.246 & \pm 0.333 & \pm 4.3 & \pm 1.26 & \pm 1.67 & \\
Control & $0.194 \mathrm{a}$ & $0.264 \mathrm{a}$ & 31.1 & 5.73 & 7.93 & 5.76 \\
& \pm 0.080 & \pm 0.100 & \pm 2.5 & \pm 12.92 & \pm 1.64 & \\
\hline \multirow{2}{*}{ Treatment } & & & & & \\
& SDM(g) & TDM(g) & TDM(\%) & SRR & hSDR & DQI \\
\hline Spontaneous self-pollination & $0.291 \mathrm{a}$ & $0.557 \mathrm{a}$ & 45.8 & 1.13 & 4.63 & 1.26 \\
& \pm 0.160 & \pm 0.298 & \pm 6.0 & \pm 0.36 & \pm 1.10 & \\
Self-pollination & $0.413 \mathrm{a}$ & $0.729 \mathrm{a}$ & 45.4 & 1.37 & 6.11 & 1.50 \\
& \pm 0.218 & \pm 0.351 & \pm 4.3 & \pm 0.39 & \pm 2.00 & \\
Cross-pollination & $0.600 \mathrm{~b}$ & $0.844 \mathrm{ab}$ & 39.2 & 3.06 & 5.25 & 3.23 \\
& \pm 0.128 & \pm 0.228 & \pm 6.0 & \pm 1.39 & \pm 0.88 & \\
Control & $0.397 \mathrm{a}$ & $0.716 \mathrm{a}$ & 39.6 & 1.29 & 6.08 & 1.41 \\
& \pm 0.185 & \pm 0.318 & \pm 2.7 & \pm 0.31 & \pm 1.12 & \\
\hline
\end{tabular}

* Different letters indicate differences between treatments within each evaluation (90 and 180 days), compared by Tukey's test at $5 \%$.

Silva \& Pinheiro (2007) recorded the beginning of Eugenia uniflora flowering in the dry season, between August and October. In the present study, flowering occurred during the transition periods between dry and rainy seasons, a strategy that presents the advantages of drought, such as good conditions for pollination, and rainfall, fruit maturation and density increase of seed dispersal animals (Proença \& Gibbs 1994, Tabarelli \& Peres 2002).

Variations in bud, flower and fruit production peaks observed each year can be related to changes in rainfall patterns in the study area. These changes also affected the production of fruits and seeds between the years of study, as can be observed in the variation in reproductive success between pollination treatments and in the control group. The maintenance of plant and animal species is determined by plant reproductive phenology (Boulter et al. 2006). Any change at the beginning of flowering or ripening of fruits may significantly alter reproductive success, seed dispersal and germination, and the establishment of plants, as well as affect the animals that depend on their resources (Newstrom et al. 1994).
According to the controlled pollination experiments, E. uniflora is a facultative xenogamous species, being able to form fruits by manual and spontaneous self-pollination, but which requires pollinators to increase its fruit set through crosspollination (Silva \& Pinheiro 2009, Franzon et al. 2010).

Authors consider that self-pollination can lead to inbreeding depression, which reduces fertility, seed viability, and vigor (Lloyd 1992, Santos et al. 2010, Diniz \& Buschini 2016). Studies indicate that self-pollination causes a low rate of seed formation compared to cross-pollination, with a large number of abortions, deformities, and mutations in seedlings and plantlets of several species (Kageyama \& PiñaRodrigues 1993, Santos Júnior et al. 2013).

According to Almeida et al. (2012), isolated populations of E. uniflora undergo genetic depression by inbreeding, with compromised pollen viability and decline in natural pollination and fruiting. However, self-pollination would guarantee the reproduction of small populations (Lloyd 1992) and the possibility 
Table 4. Germination and normal seedlings developed (NSD) from fractionated seeds of Eugenia uniflora L., according to the pollination treatment. ( $N$ : number of seeds).

\begin{tabular}{|c|c|c|c|c|c|c|c|}
\hline & \multirow{7}{*}{$\begin{array}{l}\text { two parts } \\
\text { four parts }\end{array}$} & \multicolumn{2}{|c|}{ Cross-pollination } & \multicolumn{2}{|c|}{ Self-pollination } & \multicolumn{2}{|c|}{ Control } \\
\hline \multirow{8}{*}{2015} & & \multicolumn{6}{|c|}{ Germinated fractions/seeds* (\%) } \\
\hline & & $N$ & -- & $N$ & -- & $N$ & -- \\
\hline & & 26 & 156.0 & 7 & 157.1 & 40 & 155.3 \\
\hline & & 26 & 216.6 & 7 & 166.6 & 40 & 194.3 \\
\hline & & \multicolumn{6}{|c|}{ NSD seedlings/seeds** (\%) } \\
\hline & & $N$ & -- & $N$ & -- & $N$ & -- \\
\hline & two parts & 26 & 121.7 & 7 & 100 & 40 & 112.9 \\
\hline & four parts & 26 & 121.7 & 7 & 100 & 40 & 118.8 \\
\hline \multirow{8}{*}{2016} & & \multicolumn{6}{|c|}{ Germinated fractions/seeds* (\%) } \\
\hline & & $N$ & -- & $N$ & -- & $N$ & -- \\
\hline & two parts & 48 & 179.2 & 13 & 141.7 & 60 & 112.7 \\
\hline & four parts & 48 & 280.4 & 13 & 190.0 & 60 & 150.0 \\
\hline & & \multicolumn{6}{|c|}{ NSD seedlings/seeds** (\%) } \\
\hline & & $N$ & -- & $N$ & -- & $N$ & -- \\
\hline & two parts & 48 & 112.5 & 13 & 83.3 & 60 & 74.5 \\
\hline & four parts & 48 & 191.3 & 13 & 83.3 & 60 & 79.6 \\
\hline
\end{tabular}

* Percentage of germinated fractions per seeds $(N)$; **. Normal seedlings developed per seeds $(N)$.

of reproduction in periods where there is absence or low abundance of pollinators (Proença \& Gibbs 1994, Silva \& Pinheiro 2009, Santos et al. 2010).

Among the conditions that affect the quantity and quality of pollen available to plants that need animal vectors, there is the presence of efficient and frequent pollinators in their area of occurrence (Wilson \& Thomson 1991, Kasagi \& Kudo 2003). Eugenia uniflora is an important source of food for several species of native and exotic bees, contributing to their conservation while they contribute to the reproduction and establishment of the plant (Diniz \& Buschini 2016).

In the study area, the most frequent and abundant floral visitor was the Africanized Apis mellifera. This species acts as a "pollen thief" (sensu Inouye 1980) because it collects the grains dispersed in the flowers, but only pollinates them accidentally. In addition, studies show that competition with A. mellifera may alter the foraging pattern of some native bees, which are effective pollinators of Myrtaceae, shifting them to other sources and consequently reducing their diversity and frequency of visits (Gressler et al. 2006, Silva \& Pinheiro 2007, Fidalgo \& Kleinert 2009, Diniz \& Buschini 2016).
The bees Augochloropsis sp. and Bombus sp. presented a buzzing behavior for pollen collection, removing it from the anthers more effectively. However, the first species is small, and individually carries less pollen than Bombus sp., whose body size allows collecting and depositing a greater amount of pollen grains on the stigma, being efficient in pollination (Nic Lughadha \& Proença 1996, Fidalgo $\&$ Kleinert 2009). However, Bombus sp. was observed with low frequency in the study area and could not be considered an effective pollinator (sensu Freitas 2013).

Thus, in this work, it was possible to observe a restricted number of pollinators available, whose behavior and/or body size would not be the most adequate to optimize pollination efficiency. In addition, the higher reproductive success rate in manual crosspollination compared to the control group indicate the occurrence of pollen limitation in the study area (IPL 0.76/0.90). For Ashman et al. (2004), extreme levels of pollen limitation on seed production are observed in plants that occur in environments fragmented and subject to environmental disturbance.

For fruiting species, germination rates above $80 \%$ indicate high germinative potential (Carvalho et al. 1998). The results obtained demonstrate a high 

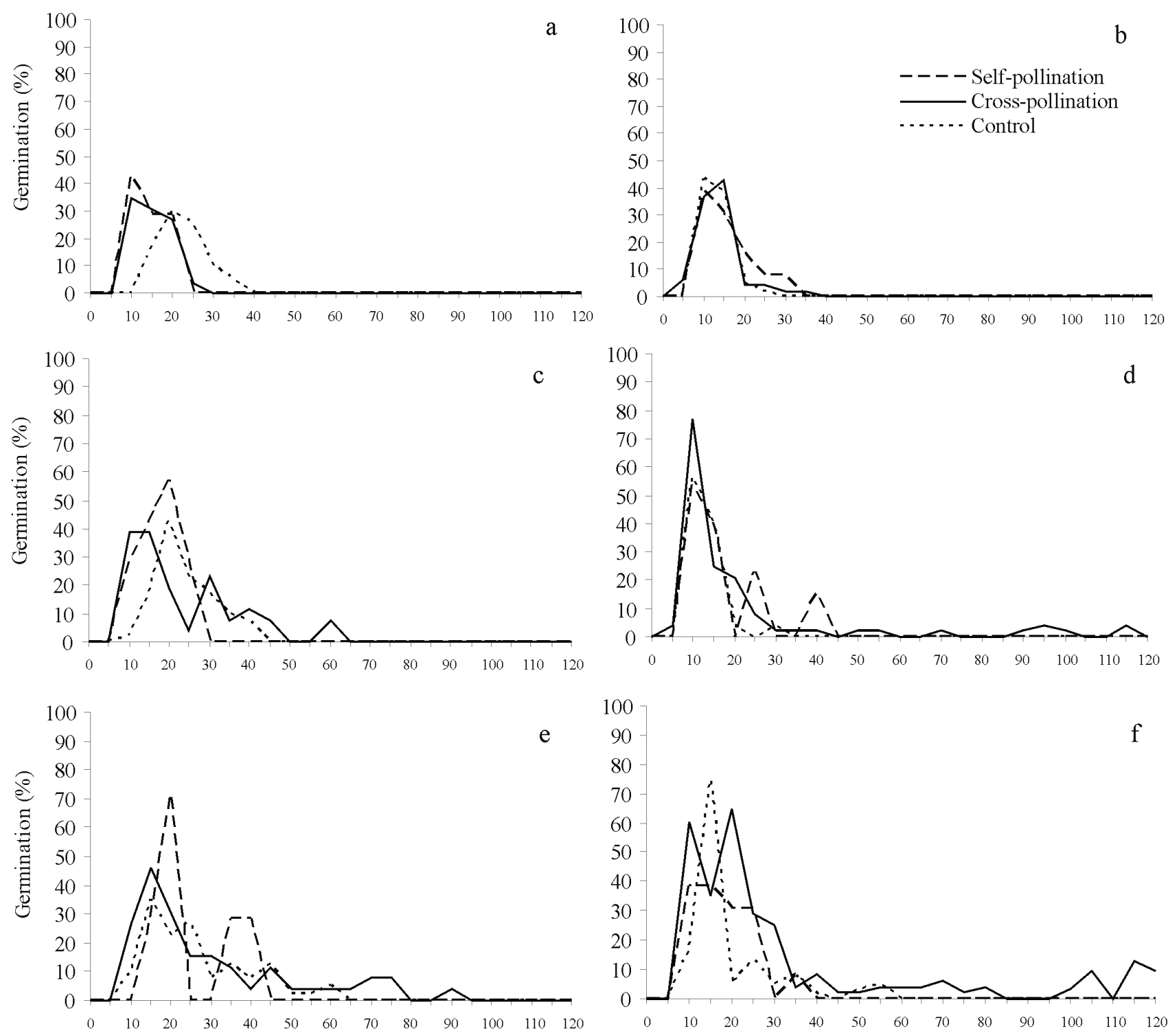

2015

Days

Figure 3. Temporal distribution (days) in 2015 (left) and 2016 (right) of Eugenia uniflora L. germination rates (\%) for seeds: intact (a-b), fractionated into two (c-d) and four (e-f) parts, according to the pollination treatment.

germinative capacity of $E$. uniflora seeds from manual pollination and control group in the study area, with small variations between the years.

Seeds from manual and spontaneous selfpollination germinated and formed normal seedlings more quickly. In cross-pollination, the seed germination peak was later and the development of normal seedlings was slower and constant, with no defined peaks.

The germination speed is considered one of the main parameters to determine the vigor of a seed batch (Vieira \& Carvalho 1994, Santana \& Ranal 2004).
However, considering that the germination test is conducted under favorable conditions of temperature, light, substrate, and humidity, allowing the batch to express the maximum potential, complementary tests are necessary to determine their vigor with greater reliability (Guedes et al. 2009).

The data obtained in the two-week evaluations suggest that the Brazilian cherry plantlets from cross-pollination grow in height and diameter faster than plantlets obtained from the other treatments. In addition, they present better shoot height/stem 

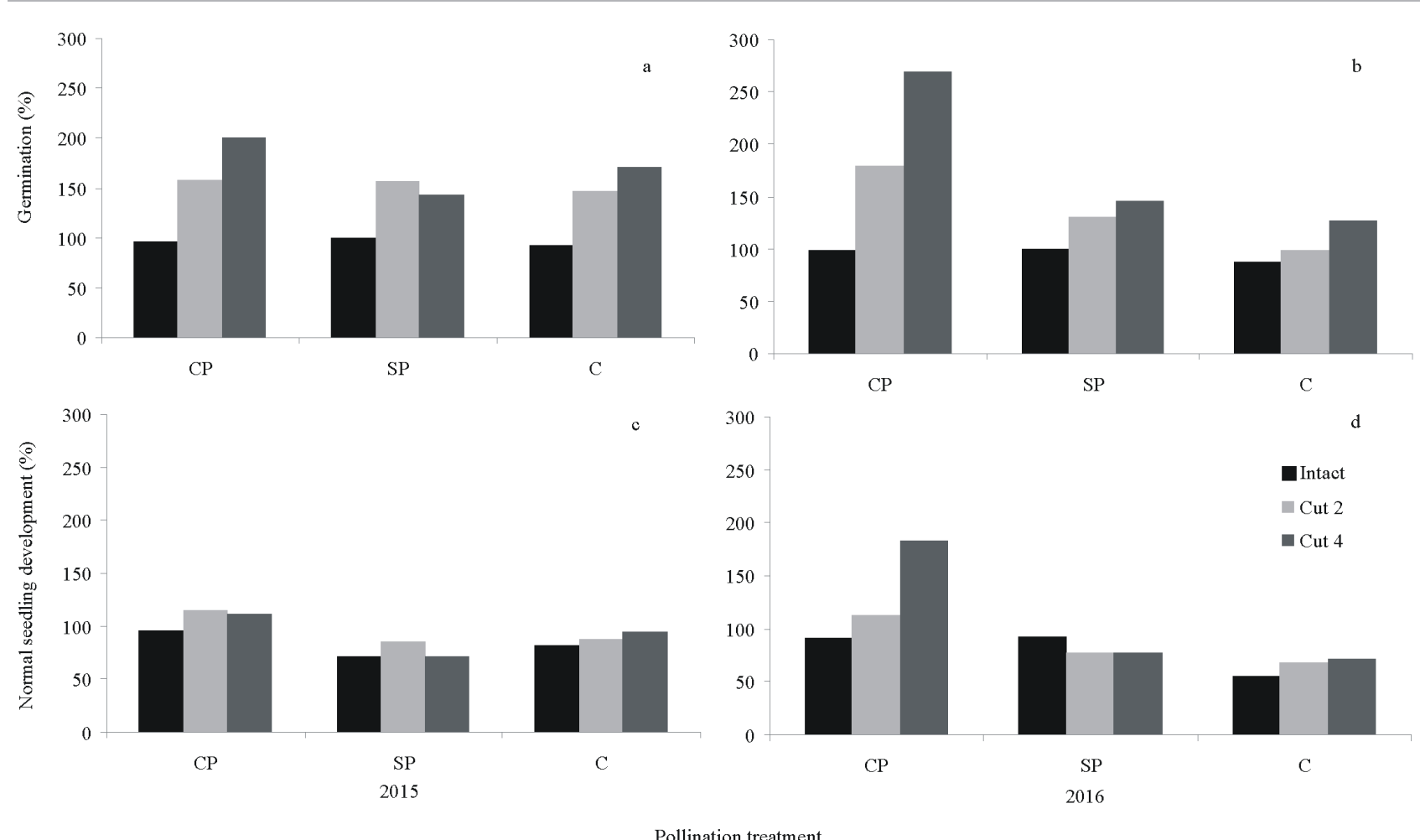

Figure 4. Percentage of germination (a-b) and normal seedling development (c-d), in 2015 (left) and 2016 (right), for Eugenia uniflora L. intact seeds, and fractioned seeds into two (Cut 2) and four (Cut 4) parts, according to the pollination treatment. (CP: cross-pollination, SP: self-pollination, C: control).

diameter ratio (hSDR), better balance in biomass distribution (SRR) and better quality indexes (DQI), especially at 180 days. These parameters are considered important for estimating plantlets growth in the field, its balance and robustness (Carneiro 1995, Caldeira et al. 2012) and confirm the best quality of plantlets from cross-pollination.

Regarding the fractioning and regeneration capacity, only seeds from cross-pollination showed more than $100 \%$ of germination and normal seedling formation during the two-year study period. In addition, in 2016, the self-pollination treatment showed a reduction in the number of normal seedlings formed after fractioning.

Seeds of E. uniflora cut in two parts, when added the values of the two halves placed to germinate (with and without the yarn), exceeded $100 \%$ of germination, but not with normal seedlings (Silva et al. 2005). Delgado et al. (2010) verified that even fractions containing $1 / 4$ of the seed were able to produce normal seedlings in E. cerasiflora, E. umbelliflora, and E. pruinosa.

According to Delgado (2010), meristematic tissues capable of differentiating and forming new embryos from the tissues of the cotyledonary vascular region could be responsible for the ability to produce seedlings from just fractions of seeds in Eugenia. However, considering Eugenia uniflora is a monoembrionic, non-apomictic species (Gurgel \& Sobihe Sobrinho 1951, Nic Lughadha \& Proença 1996, Silva \& Pinheiro 2009) such meristematic tissues cannot be associated to supernumerary embryos originated by apomixis.

The ability to produce seedlings from just fractions of seeds in Eugenia species reveal an interesting strategy for propagation and may be related to a co-evolution with predatory insects. Seeds with more than half of the cotyledons consumed by insect larvae are frequently found and are still able to germinate (Teixeira e Barbedo 2012). Therefore, reserves are produced in quantities much higher than those required for producing new seedlings. However, despite these seeds being able of producing new roots and even entire seedlings from cotyledon cells, it is rare the formation of more than one root or seedling from a single seed at the same time. This allows the same seed to experience adverse conditions without necessarily losing the ability to propagate the species (Barbedo 2018 and references therein). 
In the present study, a single seed from selfpollination produced more than one normal seedling when sectioned. One can think that the seeds from this treatment for some reason present a failure in regeneration but this did not occur due to lack of nutritional reserve since at least a fraction of the seeds that germinated were able to form normal seedlings.

In general, manual cross-pollination showed the best results on reproductive success, seedling production, and fractioning and germination experiments. Seeds from cross-pollination were the most vigorous and plantlets presented higher quality. The lower performance of natural pollination in the evaluated parameters shows the pollen limitation generated by the lack of efficient pollinators in the study area.

\section{Aknowledgements}

The authors are grateful to MSc Lilian M. Asperti, for her help in conducting the greenhouse experiment and the quality evaluation of the plantlets; to the Instituto de Botânica (IBt) for allowing to collect the seeds and, the CNPq for the scholarship granted to A.T. Cécel and J.F.O. Mazzi and, researcher fellowship granted to C.J. Barbedo. J.R. Lima reviewed the English manuscript.

\section{Literature cited}

Almeida D.J., Faria M.V. \& Silva P.R. 2012. Effect of forest fragmentation on microsporogenesis and pollen viability in Eugenia uniflora, a tree native to the Atlantic Forest. Genetic and Molecular Research 6: 11: 4245-55.

Amador, T.S. \& Barbedo, C.J. 2011. Potencial de inibição da regeneração de raízes e plântulas em sementes germinantes de Eugenia pyriformis. Pesquisa Agropecuária Brasileira 46: 814-821.

Ashman, T.L, Knight, T.M., Steets, J.A., Amarasekare, P., Burd, M., Campbell, D.R., Dudash, M.R., Johnston, M.O., Mazer, S.J., Mitchell, R.J., Morgan, M.T. \& Wilson, W.G. 2004. Pollen limitation of plant reproduction: ecological and evolutionary causes and consequences. Ecology 85: 2408-2421.

Barbedo, C.J. 2018. New approach towards the so-called recalcitrant seeds. Journal of Seed Science 40: 219-234.

Barringer, B.C. 2007. Polyploidy and self-fertilization in flowering plants. American Journal of Botany 94: 1527-1533.

Batschelet, E. 1981. Circular statistics in biology. Academic Press, London.

Beardsell, D.V., O'Brien, S.P., Williams, E.G., Knox, R.B \& Calder, D.M. 1993. Reproductive biology of Australian Myrtaceae. Australian Journal of Botany 41: 511-526.
Bezerra, J.E.F., Silva Júnior, J.F. \& Lederman, I.E. 2000. Pitanga (Eugenia uniflora L.). Série Frutas Nativas 1. Fundação de Apoio à Pesquisa, Ensino e Extensão, Jaboticabal.

Boulter, S.L., Kitching, R.L., \& Howlett, B.G. 2006. Family, visitors and the weather: patterns of flowering in tropical rain forests of northern Australia. Journal of Ecology 94: 369-82.

Caldeira, M.V.W., Delarmelina, W.M., Lübe, S.G., Gomes, D.R., Gonçalves, E.O. \& Alves, A.F. 2012. Biossólido na composição de substrato para a produção de mudas de Tectona grandis. Floresta 42: 77-84.

Carneiro, J.G.A. 1995. Produção e controle de qualidade de mudas florestais. Universidade Federal do Paraná. Fundação de Pesquisas Florestais do Paraná, Curitiba.

Carvalho, J.E.U., Nascimento, W.M.O. \& Muller, C.H. 1998. Características físicas e de germinação de sementes de espécies frutíferas nativas da Amazônia. Belém. EMBRAPA. Centro de Pesquisa Agroflorestal da Amazônia Oriental, Belém.

CEPAGRI - Centro de Pesquisas Meteorológicas e Climáticas aplicadas à Agricultura. 2012. Clima dos Municípios Paulistas. Available at http://www.cpa. unicamp.br/outras-informacoes/clima-dos-municipiospaulistas.html (access in 30-XI-2012).

Dafni, A, Kevan, P.G. \& Husband, B.C. 2005. Practical Pollination Biology. Environquest, Ontario.

Delgado, L.F. 2010. Fracionamento, maturação e origem da capacidade regenerativa de sementes de algumas espécies brasileiras de Eugenia (Myrtaceae). Tese de Doutorado, Instituto de Botânica, São Paulo.

Delgado, L.F. \& Barbedo, C.J. 2007. Tolerância à dessecação de sementes de espécies de Eugenia. Pesquisa Agropecuária Brasileira 42: 265-272.

Delgado, L.F., Mello, J.I.O. \& Barbedo, C.J. 2010. Potential for regeneration and propagation from cut seeds of Eugenia (Myrtaceae) tropical tree species. Seed Science Technology 38: 624-634.

Dickson, A., Leaf, A.L. \& Hosner, J.F. 1960. Quality appraisal of white spruce and white pine seedling stock in nurseries. Forestry Chronicle 36: 10-13.

Diniz, M.E.R. \& Buschini, M.L.T. 2016. Diversity of flower visiting bees of Eugenia uniflora L. (Myrtaceae) in fragments of Atlantic Forest in South Brazil. Sociobiology 63: 982-990.

Ferreira, D.F. 1999. SISVAR 4.3 - Sistema de análises estatísticas. UFLA, Lavras (Software estatístico).

Fidalgo, A.O. \& Kleinert, A.M.P. 2009. Reproductive biology of six Brazilian Myrtaceae: is there a syndrome associated with buzz-pollination? New Zeland Journal of Botany 47: 355-365.

Fonseca, E.P., Valéri, S.V., Miglioranza, E., Fonseca, N.A.N. \& Couto, L. 2002. Padrão de qualidade de mudas de Trema micrantha (L.) Blume, produzidas sob diferentes períodos de sombreamento. Revista Árvore 26: 515-523. 
Franzon, R.C., Castro, C.M. \& Raseira, M.C.B. 2010. Variabilidade genética em populações de pitangueira oriundas de autopolinização e polinização livre, acessada por AFLP. Revista Brasileira de Fruticultura 32: $240-250$.

Freitas, L. 2013. Concepts of pollinator performance: is a simple approach necessary to achieve a standardized terminology? Brazilian Journal of Botany 36: 3-8.

Freitas, L., Wolowski, M. \& Sigiliano, M.I. 2010. Ocorrência de limitação polínica em plantas de Mata Atlântica. Oecologia Australis 14: 251-265.

Gressler, E., Pizo, A.M. \& Morelato, C.P.L. 2006. Polinização e dispersão de sementes em Myrtaceae do Brasil. Revista Brasileira de Botânica 29: 509-530.

Guedes, R.S., Alves, E.U., Gonçalves, E.P., Santos, S.R.N. \& Lima, C.R. 2009. Testes de vigor na avaliação da qualidade fisiológica de sementes Erythrina velutina Willd. (Fabaceae-Papilionoideae). Ciência e Agrotecnologia 33: 1360-1365.

Gurgel, J.T.A. \& Soubihe Sobrinho, J. 1951. Poliembrionia em mirtáceas frutíferas. Bragantia 11: 141-163.

Inouye, D.W. 1980. The terminology of floral larceny. Ecology 61: 1251-1253.

Kageyama, P.Y. \& Piña-Rodrigues, F.C.M. 1993. Fatores que afetam a produção de sementes. In: I.B. Aguiar, F.C.M. Piña-Rodrigues \& M.B. Figliolia (eds.). Sementes florestais tropicais. ABRATES, Brasília, pp.19-46.=

Kasagi, T., \& Kudo, G. 2003. Variations in bumblebee preference and pollen limitation among neighboring populations: comparisons between Phyllodoce caerulea and Phyllodoce aleutica (Ericaceae) along snowmelt gradients. American Journal of Botany 90:1321-1327.

Köppen, W. 1948. Climatologia: con un estudio de los climas de la tierra. Fondo de Cultura Económica, México.

Larson, B.M.H. \& Barrett, S.C.H. 2000. A comparative analysis of pollen limitation in flowering plants. Biological Journal of the Linnean Society 69: 503-520.

Lloyd, D.G. 1992. Self and cross-fertilization in plants. II. The selection of self-fertilization. International Journal of Plant Sciences 151: 370-380.

Newstrom, L.E., Frankie, G.W. \& Baker, H.G. 1994. A new classification for plant phenology based on flowering patterns in lowland tropical rain forest trees at La Selva, Costa Rica. Biotropica 26: 141-59.
Nic Lughadha, E. \& Proença, C. 1996. A survey of the reproductive biology of the Myrtoideae (Myrtaceae). Annais of the Missouri Botanical Garden 83: 480-503.

Proença, C. \& Gibbs, P.E. 1994. Reproductive biology of eight sympatric Myrtaceae from Central Brazil. New Phytologisty 126: 343-354.

Rodrigues, S.S., Fidalgo, A.O., Barbedo, C.J. 2017. Reproductive biology and production of seeds and seedlings of Campomanesia pubescens (DC.) O. Berg. Journal of Seed Science 39: 272-279.

Santana, D.G. \& Ranal, M.A. 2004. Análise da germinação: um enfoque estatístico. Editora UnB, Brasília.

Santos, A.P.M., Romero, R. \& Oliveira, P.E.A.M. 2010. Biologia reprodutiva de Miconia angelana (Melastomataceae), endêmica da Serra da Canastra, Minas Gerais. Revista Brasileira de Botânica 33: 333-341.

Santos Júnior, A., Tomas, W.M., Jorge, M.H.A. \& Hay, J.D.V. 2013. Efeito do isolamento de árvores de Sterculia apetala sobre a emergência de plântulas no pantanal. Biotemas 26: 61-67.

Silva, A.L.G. \& Pinheiro, M.C.B. 2007. Biologia floral e da polinização de quatro espécies de Eugenia L. (Myrtaceae). Acta Botanica Brasilica 21: 235-247.

Silva, A.L.G. \& Pinheiro, M.C.B. 2009. Reproductive success of four species of Eugenia L. (Myrtaceae). Acta. Botanica Brasilica 23: 526-534.

Silva, C.V., Bilia, D.A.C., Maluf, A.M. \& Barbedo, C.J. 2003. Fracionamento e germinação de sementes de uvaia (Eugenia pyriformis Cambess. - Myrtaceae). Revista Brasileira de Botânica 26: 213-221.

Silva, C.V., Bilia, D.A.C. \& Barbedo, C.J. 2005. Fracionamento e germinação de sementes de Eugenia. Revista Brasileira de Sementes 27: 86-92.

Tabarelli, M. \& Peres, C.A. 2002. Abiotic and vertebrate seed dispersal in the Brazilian Atlantic forest: implications for forest regeneration. Biological Conservation 106: 165-176.

Teixeira, C.C. \& Barbedo, C.J. 2012. The development of seedlings from fragments of monoembryonic seeds as an important survival strategy for Eugenia (Myrtaceae) tree species. Trees 26: 1069-1077.

Vieira, R.D. \& Carvalho, N.M. 1994. Testes de vigor em sementes. FUNEP, Jaboticabal.

Wilson, P.S., \& Thomson, J.D. 1991. Heterogeneity among floral visitors leads to discordance between removal and deposition of pollen. Ecology 72: 1503-1507.

Zar, J.H. 1999. Bioestatistical analysis. Prentice Hall, Upper Saddle River. 